\title{
DAMPAK KEPUTUSAN INVESTASI DAN STRUKTUR KEPEMILIKAN KELUARGA TERHADAP KOMPENSASI DIREKSI PERUSAHAAN MANUFAKTUR INDONESIA
}

\author{
Surtihati, Cynthia Afriani Utama \\ Departemen Manajemen Fakultas Ekonomi dan Bisnis Universitas Indonesia \\ Kampus UI Depok Universitas Indonesia \\ Jl.Prof. Dr. Sumitro Djojohadikusumo, Depok, 16424, Indonesia
}

\section{Abstract}

Keywords: Agency Problem, CEO Compensation, Family Ownership Structure, Firm's Growth, Investment Decisions,

This study examined the influence of family ownership structure and investment decisions to CEO compensation. This study also examined how the family ownership structure and investment decisions jointly affected CEO compensation. This study used 988 observations consisting of 150 manufacturing companies listed in Indonesia Stock Exchange from 2008 to 2014. The method used was fixed effects method (FEM). The results of the study showed that firms owned by a family gave higher compensation than non-family firms to their CEO. The family ownership structure proved strengthen the positive relationship between investment decisions and CEO compensation.

\section{JEL Classification:} G11, G32, M12

Kata Kunci:
Masalah
Keagenan,
Kompensasi
Direksi, Struktur
Kepemilikan
Keluarga,
Pertumbuhan
Perusahaan,
Keputusan
Investasi

Abstrak

Penelitian ini bertujuan untuk menguji pengaruh struktur kepemilikan keluarga dan keputusan investasi terhadap jumlah kompensasi direksi. Penelitian ini juga menguji bagaimana struktur kepemilikan keluarga dan keputusan investasi secara bersama-sama memengaruhi kompensasi direksi perusahaan. Penelitian ini menggunakan 988 observasi yang terdiri dari 150 perusahaan sektor manufaktur yang terdaftar di Bursa Efek Indonesia (BEI) pada tahun 2008-2014. Metode penelitian yang digunakan adalah metode efek tetap (MET). Hasil dari penelitian menemukan bahwa perusahaan yang dimiliki oleh sebuah keluarga akan memberikan kompensasi kepada direksinya lebih tinggi dibandingkan perusahaan non-keluarga. Struktur kepemilikan keluarga terbukti memperkuat hubungan positif antara keputusan investasi dengan jumlah kompensasi direksi.
\end{abstract}


Masalah keagenan terjadi ketika agen memanfaatkan kesenjangan informasi untuk membuat keputusan yang menguntungkan dirinya sendiri dan hal ini akan mengakibatkan kerugian di pihak prinsipal (Jensen \& Meckling, 1976). Menurut Wicaksono (2000) dalam Utama (2003), keberhasilan penerapan corporate governance tak lepas dari struktur kepemilikan sebuah perusahaan. Claessens \& Fan (2002) menyatakan bahwa tipe struktur kepemilikan memiliki peran dalam menentukan jenis masalah keagenan yang ada. Jensen \& Meckling (1976) berpendapat bahwa kompensasi yang kompetitif menjadi salah satu solusi dalam masalah keagenan. Pentingnya kompensasi direksi terkait keberlangsungan sebuah perusahaan sudah menjadi hal yang diakui dengan beberapa penelitian sebelumnya, seperti penelitian oleh Brick et al. (2006), Croci et al. (2012), Gallego \& Larrain (2012), Wu (2013), Adhikari et al. (2015), Cheng et al. (2015), dan Tsao et al. (2015).

Menurut Claessens et al. (2000), lebih dari $2 / 3$ perusahaan yang ada di Indonesia adalah perusahaan yang dikontrol dan dikendalikan oleh sebuah keluarga. Price Waterhouse Coopers (PWC) tahun 2014 menyatakan bahwa 95\% perusahaan yang ada di Indonesia merupakan perusahaan keluarga. Perusahaan keluarga memiliki isu khusus mengenai perilaku pemegang saham mayoritas ketika grup keluarga terorganisasi dalam struktur piramida (Morck \& Yeung, 2003). Perusahaan keluarga di Indonesia menganut sistem struktur piramida. Penelitian terdahulu menyatakan bahwa konflik kepentingan antara pemegang saham minoritas dan pemegang saham pengendali perusahaan keluarga terkait dengan kegiatan ekstraksi manfaat pribadi oleh pemegang saham mayoritas (Benos \& Weisbach, 2004).

Insentif pemegang saham mayoritas perusahaan keluarga dapat berubah jika ia mengadopsi struktur piramida dengan perbedaan hak voting dan cash flow right (CFR) (Cheng et al., 2015). Hubungan positif antara hak voting yang berlebih dari pemegang saham pengendali dan kompensasi dewan ditemukan oleh Barontini \& Bozzi (2011). Cheng et al. (2015) menemukan bahwa hak voting yang berlebih akan memengaruhi peran pemegang saham pengendali perusahaan keluarga dan anggota keluarga lainnya dalam kompensasi eksekutif, hasil dari penelitiannya menemukan bahwa hak voting pemegang saham pengendali yang melebihi CFR berkaitan dengan kompensasi eksekutif yang lebih tinggi. Barontini \& Bozzi (2011) menunjukkan bahwa perusahaan keluarga di Italia membayar direktur utamanya lebih tinggi daripada perusahaan lainnya, dan membayar direktur utama keluarga lebih tinggi daripada direktur utama profesional. Jumlah kompensasi eksekutif yang lebih tinggi ditemukan pada perusahaan dengan struktur kepemilikan keluarga juga ditemukan oleh Barontini \& Caprio (2006), Cohen \& Lauterbach (2008), dan Gallego \& Larrain (2012).

Tsao et al. (2015) menemukan hubungan positif antara pertumbuhan perusahaan dengan jumlah kompensasi yang diberika investasi jangka panjang. Pengalokasian dana lebih kepada investasi akan membuat potensi ekstraksi manfaat oleh pemegang saham mayoritas berkurang, keberhasilan investasi yang membuat pemegang saham mendapatkan imbal hasil lebih besar dapat memperkecil konflik antara pemegang saham mayoritas dan minoritas.

Pemegang saham perusahaan keluarga lebih fokus pada investasi (Anderson \& Reeb, 2003; Brenes et al., 2011; Tsao et al., 2015) sehubungan dengan kepemilikan saham perusahaan keluarga yang bersifat tidak terdiversifikasi. Hal ini yang membuat mereka memberikan kompensasi lebih tinggi ketika pemilihan investasi yang dilakukan berhasil, pandangan mereka terhadap pertumbuh' an perusahaan menjadi lebih kuat dengan hasil berupa kompensasi yang lebih tinggi. Melihat pentingnya kompensasi direksi dalam kegiatan operasional, pengurangan masalah keagenan, dan kelangsungan hidup sebuah perusahaan, peneliti 
tertarik menguji pemberian kompensasi direksi. Pada umumnya penelitian-penelitian terdahulu melihat hubungan langsung antara struktur kepemilikan keluarga dan keputusan investasi dengan kompensasi direksi. Belum ada penelitian yang menginvestigasi pengaruh struktur kepemilikan keluarga terhadap hubungan antara keputusan investasi dengan jumlah kompensasi direksi. Selain itu, hanya beberapa artikel yang menggunakan negara emerging market sebagai sampel. Sebagian besar penelitian yang berfokus pada bisnis keluarga cenderung mengambil negara Amerika Serikat dan Eropa sebagai sampel seperti yang dikatakan oleh De Massis et al. (2012) dalam Cheng et al. (2015). Perusahaan dengan struktur kepemilikan keluarga akan melibatkan banyak interaksi antar anggota keluarga di dalamnya, hal ini membuat struktur kepemilikan keluarga menarik untuk diinvestigasi apakah struktur kepemilikan keluarga akan menjadi moderator dalam hubungan antara keputusan investasi dengan kompensasi direksi.

\section{PENGEMBANGAN HIPOTESIS}

\section{Perusahaan Keluarga dan Kompensasi Direksi}

Perusahaan keluarga memiliki isu khusus mengenai perilaku pemegang saham mayoritas terutama ketika grup keluarga terorganisasi dalam struktur piramida (Morck \& Yeung, 2003). Cheng et al. (2015) menemukan bahwa hak voting pemegang saham pengendali yang melebihi CFR berkaitan dengan kompensasi eksekutif yang lebih tinggi. Ketika pemegang saham pengendali menjadi direktur utama perusahaan dan menghadapi pemisahan yang besar antara kepemilikan dengan pengelolaan, maka tingkat kompensasi akan meningkat (Amoako-Adu et al., 2011). Jumlah kompensasi eksekutif lebih tinggi pada perusahaan keluarga juga ditemukan oleh Barontini \& Caprio (2006), Cohen \& Lauterbach (2008), dan Gallego \& Larrain (2012). Struktur piramida di Indonesia membuat pemegang saham pengendali memiliki hak voting yang berlebih dari CFR-nya sehingga pemberian kompensasi pada perusahaan keluarga di Indonesia akan cenderung lebih tinggi. Dari kajian konsep dan empiris tersebut, maka ditarik hipotesis 1 sebagai berikut:

$\mathrm{H}_{1}$ : struktur kepemilikan keluarga di Indonesia membuat tingkat kompensasi yang diterima oleh direksi perusahaan setiap tahunnya menjadi lebih tinggi.

\section{Pertumbuhan Perusahaan dan Kompensasi Direksi}

Pertumbuhan terkait dengan kenaikan kinerja perusahaan sehingga reward akan diberikan kepada direksi sebagai bentuk apresiasi perusahaan. Pemberian reward ini akan membuat kompensasi yang diterima oleh manajemen menjadi lebih besar (Murphy, 1985). Pihak manajemen perusahaan mengharapkan pemberian kompensasi didasarkan kepada hasil dari keputusan investasi yang mereka lakukan (Coles et al., 2001). Keputusan investasi dinilai berhasil dengan pertumbuhan yang tinggi, maka dari itu pemegang saham menghubungkan jumlah kompensasi yang diterima dengan peluang pertumbuhan perusahaan. Hal ini sejalan dengan hasil penelitian dari Adhikari et al. (2015), Cheng et al. (2015), dan Tsao et al. (2015), yang menemukan bahwa pemegang saham yang menginginkan pertumbuhan yang lebih tinggi akan memotivasi manajemennya dengan memberikan kompensasi yang lebih tinggi. Dari kajian konsep dan empiris tersebut, maka ditarik hipotesis 2 sebagai berikut:

$\mathrm{H}_{2}$ : pertumbuhan perusahaan akan meningkatkan jumlah kompensasi yang diterima oleh direksi perusahaan menjadi lebih besar.

\section{Pertumbuhan Perusahaan Keluarga dan Kompensasi Direksi}

Perusahaan keluarga cenderung memiliki pertumbuhan perusahaan yang tinggi jika diban- 
dingkan dengan perusahaan non-keluarga (Tsao et al., 2015). Cheng et al. (2015) menemukan bahwa pertumbuhan perusahaan membuat pemberian kompensasi direksi perusahaan keluarga menjadi lebih tinggi. Hal ini karena pemegang saham perusahaan keluarga lebih fokus pada investasi (Anderson \& Reeb, 2003; Brenes et al., 2011; Tsao et al., 2015) sehubungan dengan kepemilikan saham perusahaan keluarga yang bersifat tidak terdiversifikasi, sehingga mereka akan cenderung menyukai investasi dibandingkan dengan keuntungan jangka pendek. Hal ini akan membuat pandangan mereka mengenai pertumbuhan perusahaan menjadi lebih kuat. Dari kajian konsep dan empiris tersebut, maka ditarik hipotesis 3 sebagai berikut:

Tabel 1. Variabel dan Pengukuran Variabel Penelitian

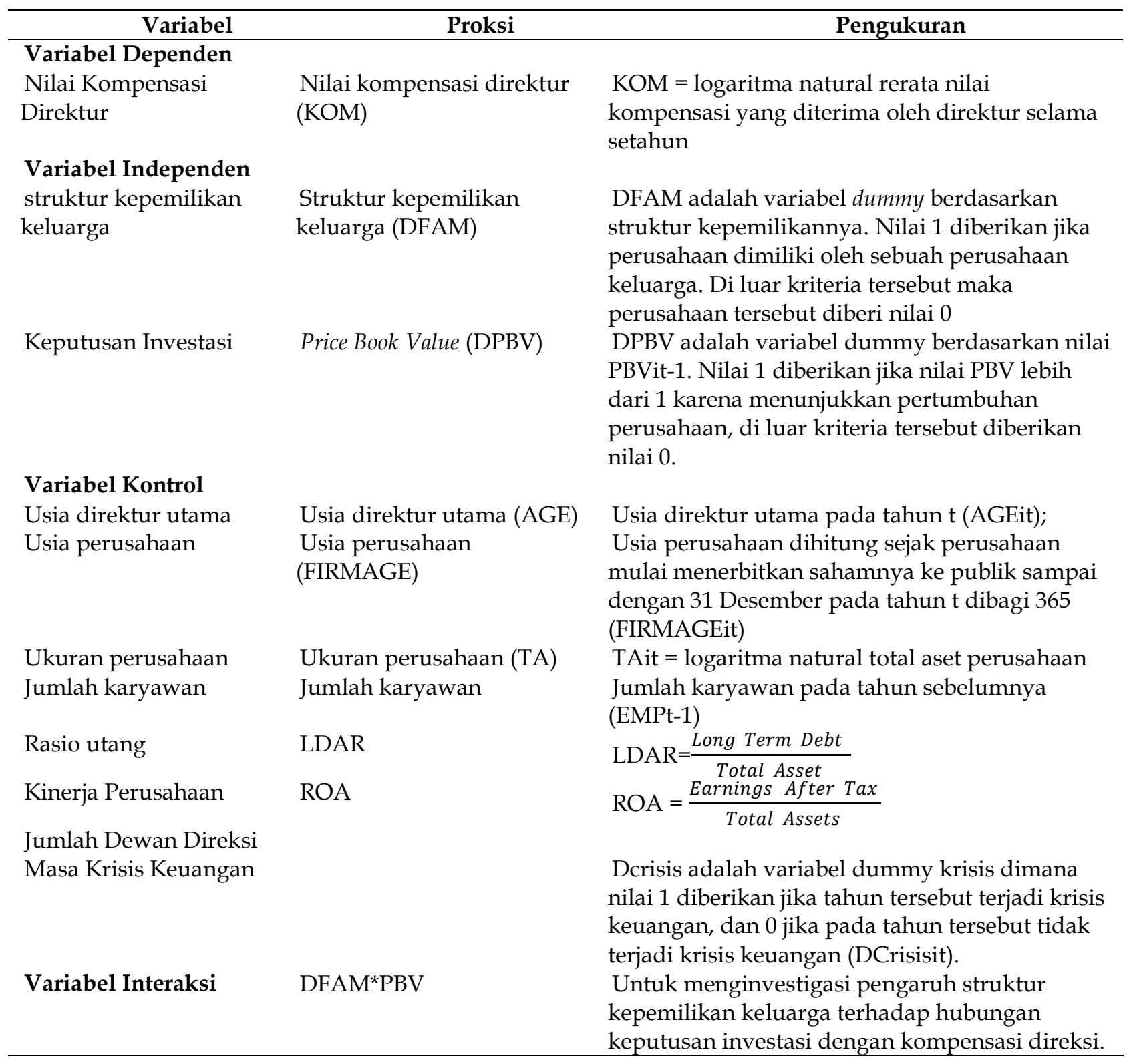


$\mathrm{H}_{3}$ : hubungan positif antara pemberian jumlah kompensasi direksi perusahaan dengan pertumbuhan perusahaan akan lebih kuat terjadi pada perusahaan keluarga dibandingkan pada perusahaan non-keluarga.

\section{METODE}

Populasi dari penelitian ini adalah seluruh perusahaan yang terdaftar di BEI pada tahun 20082014. Pemilihan sampel menggunakan teknik purposive sampling dilakukan dengan beberapa kriteria. Pertama, perusahaan manufaktur yang temasuk ke dalam sektor aneka industri dan alat berat, barang konsumsi, dan industri dasar dan kimia berdasarkan daftar perusahaan di ICMD tahun 2008-2014. Kedua, perusahaan yang delisting atau perusahaan yang baru melakukan IPO (Initial Public Offering) pada periode pengujian sampel akan dieliminasi. Ketiga, perusahaan yang menampilkan informasi jumlah kompensasi yang diberikan kepada direksi pada tahun 2008-2014.

Peneliti menggunakan data sekunder berupa dari laporan keuangan, laporan tahunan, Direktori Pasar Modal Indonesia (ICMD), dan data stream Fakultas Ekonomi dan Bisnis UI. Laporan tahunan dan laporan keuangan perusahaan diperoleh melalui website BEI. Pemilihan sampel menggunakan teknik purposive sampling, yakni perusahaan terbuka yang sahamnya terdaftar di BEI dan memberikan laporan keuangan serta laporan tahunan secara resmi ke BEI pada tahun 2008-2014.

\section{Model Penelitian}

Berdasarkan penelitian yang dilakukan oleh Cheng et al. (2015), Tsao et al. (2015), dan Adhikari et al. (2015), maka model empiris penelitian dapat dilihat pada persamaan di bawah ini:

$\begin{aligned} \operatorname{KOM}_{\mathrm{i}}(t)= & \alpha_{1}+\alpha_{2} \operatorname{DFAM}_{i}(t)+\alpha_{3} D P B V_{i}(t-1)+ \\ & \alpha_{4} A G E_{i}(t)+\alpha_{5} \operatorname{EMP}_{i}(t-1)+\alpha_{6} T A_{i}(t)+ \\ & \alpha_{7} L E V_{i}(t)+\alpha_{8} R_{1} O A_{i}(t-1)+\alpha_{9} \operatorname{EXESIZE}_{i}(t)+ \\ & \alpha_{10} \text { FIRMAGE }_{i}(t)+\alpha_{11} D \text { Crisis }_{i}(t)+ \\ & \alpha_{12} D F A M^{*} P B V_{i}(t)+e_{i}(t) \ldots \ldots(1)\end{aligned}$

Keterangan:

$\mathrm{KOM}=$ logaritma natural total kompensasi yang diterima setiap individu direksi selama setahun

DFAM = dummy variabel struktur kepemilikan keluarga, apakah perusahaan tersebut termasuk ke dalam perusahaan keluarga atau tidak

PBV = price to book value di tahun sebelumnya

AGE = usia direktur utama

LEV = rasio utang perusahaan yang diambil dari utang jangka panjang dibagi total asset

EMP = jumlah karyawan perusahaan di tahun sebelumnya

FIRMAGE $=$ usia perusahaan sejak tanggal IPO

ROA = return on asset di tahun sebelumnya

TA $=$ total asset

EXESIZE = jumlah dewan komisaris

Dimana $\mathrm{KOM}_{i t}$ adalah logaritma natural dari rata-rata total kompensasi tahunan yang diterima oleh direksi perusahaan i tahun $\mathrm{t}, \alpha_{1}$ adalah koefisien regresi, $D F A M_{i t}$ adalah dummy variabel dari struktur kepemilikan keluarga i di tahun $\mathrm{t}, P B V_{i t}$ adalah dummy variabel dari PBV perusahaan i di

Tabel 2. Statistik Deskripsi

\begin{tabular}{|c|c|c|c|c|c|c|c|c|c|c|}
\hline & KOM & DFAM & PBVt-1 & AGE & LEV & EMPt-1 & FIRM AGE & ROAt-1 & TA & EXESIZE \\
\hline Mean & 20,66 & 0,76 & 2,26 & 53,51 & 0,141175 & 4695,718 & 6416,56 & 0,057467 & 5.850 .000 .000 .000 & 4,216819 \\
\hline Maximum & 24,73 & 1 & 82,35 & 80 & 4,77 & 156097 & 13007 & 1,48 & 236.000 .000 .000 .000 & 11 \\
\hline Minimum & 17,41 & 0 & $-24,19$ & 28 & 0 & 21 & 13 & $-1,07$ & 42.700 .000 .000 & 2 \\
\hline Std. Dev. & 1,25 & 0,42 & 5,43 & 8,92 & 0,320848 & 12301,1 & 2457,45 & 0,132454 & 16.700 .000 .000 .000 & 1,748253 \\
\hline Sum & 20408,13 & 754 & 2198,82 & 52870 & 139,34 & 4634674 & 6333144 & 49673,53 & 5.780 .000 .000 .000 .000 & 139,34 \\
\hline
\end{tabular}


tahun sebelumnya, $D F A M^{*} P B V_{i t-1}$ adalah variabel interaksi antara dummy variabel struktur kepemilikan keluarga dengan nilai PBV perusahaan di tahun sebelumnya, dan $e_{i t}$ adalah error $\mathrm{t}$.

\section{HASIL}

\section{Statistik Deskriptif}

Pada hasil statistik deskriptif pada Tabel 2, kompensasi yang diterima direksi rata-rata adalah sebesar Rp2.170.000.000,00 (dalam bentuk log: 20,66). Jumlah minimum yang dibayarkan kepada direksi adalah sebesar Rp36.266.141,00 pada tahun 2008, hal ini dapat terjadi dikarenakan pada tahun 2008 terjadi krisis global yang membuat para investor asing menarik dananya dan mau tidak mau Indonesia pun menerima dampaknya dalam sektor keuangan.

Struktur kepemilikan keluarga dari hasil statistik deskriptif memiliki rata-rata sebesar 0,764 atau $76,4 \%$. Hal ini berarti bahwa $76,4 \%$ dari sampel yang digunakan oleh peneliti dimiliki oleh perusahaan keluarga, baik itu perusahaan keluarga dalam negeri atau pun perusahaan keluarga asing. Rata-rata lag pertumbuhan perusahaan adalah sebesar 2,26. Nilai PBV perusahaan yang bernilai lebih dari 1 mengindikasikan bahwa keputusan investasi perusahaan berhasil dan dinilai tepat atau setiap tahunnya rata-rata perusahaan mengalami pertumbuhan.

Dari ringkasan Tabel 3 didapatkan bahwa rata-rata jumlah kompensasi yang didapatkan oleh direksi lebih tinggi pada perusahaan keluarga dibandingkan dengan perusahaan non-keluarga, jika dilihat dari data ini maka hipotesis 1 diterima. Sedangkan pertumbuhan perusahaan lebih besar pada perusahaan non-keluarga dibandingkan dengan perusahaan keluarga, hal ini terjadi karena perusahaan non-keluarga memiliki ukuran yang lebih kecil sehingga kemungkinan berkembang lebih cepat daripada perusahaan yang berukuran lebih besar.

MET terpilih sebagai metode terbaik setelah sebelumnya dilakukan uji Chow dan uji Hausman. Berdasarkan Tabel 4 variabel DFAM memiliki koefisien positif sebesar 0,3496 dan signifikan pada level 1\%. Hal ini menunjukkan perusahaan yang sahamnya dimiliki oleh perusahaan keluarga akan memberikan kompensasi direksi yang lebih tinggi dibandingkan pada perusahaan non-keluarga. Hal ini memiliki beberapa alasan dalam kasus di Indonesia, pertama karena perusahaan keluarga yang ada di Indonesia berkontribusi sebanyak 25\% dalam PDB yang ada di negara ini (Coopers, 2014), selain itu perusahaan keluarga di Indonesia cenderung merupakan anggota dari sebuah grup unit

Tabel 3. Statistik Deskriptif Berdasarkan Struktur Kepemilikan Perusahaan

\begin{tabular}{|c|c|c|c|c|}
\hline & \multicolumn{2}{|c|}{ Non-Keluarga } & \multicolumn{2}{|c|}{ Keluarga } \\
\hline & Mean & St.Dev & Mean & St.Dev \\
\hline $\mathrm{KOM}_{\mathrm{it}}$ & 20,49 & 1,24 & 20,71 & 1,25 \\
\hline $\mathrm{PBV}_{\mathrm{it}-1}$ & 3,41 & 5,45 & 1,9 & 5,44 \\
\hline $\mathrm{Age}_{\mathrm{it}}$ & 53,38 & 8,87 & 53,55 & 8,92 \\
\hline EXESIZE $_{\text {it }}$ & 4,38 & 1,29 & 4,17 & 1,86 \\
\hline $\mathrm{EMP}_{\mathrm{it}-1}$ & $2.814,55$ & $5.163,07$ & $5.270,42$ & $13.721,35$ \\
\hline FIRM AGE $E_{i t}$ & 19,88 & 7,69 & 16,87 & 6,24 \\
\hline $\mathrm{TA}_{\mathrm{it}}$ & 4.170.000.000.000 & 6.990 .000 .000 .000 & 6.370 .000 .000 .000 & 18.600.000.000.000 \\
\hline $\mathrm{LEV}_{\text {it }}$ & 0,07 & 0,14 & 0,16 & 0,36 \\
\hline $\mathrm{ROA}_{\mathrm{it}-1}$ & 7,96 & 15,83 & 5,07 & 12,24 \\
\hline Total Sampel & & 233 & & 755 \\
\hline
\end{tabular}


usaha perusahaan (konglomerasi), maka dari itu kemampuan perusahaan keluarga di Indonesia memberikan kompensasi pun menjadi lebih baik daripada perusahaan non-keluarga.

Tabel 3. Hasil Estimasi Regresi Panel Data Menggunakan Metode Efek Tetap (MET)

\begin{tabular}{|c|c|c|}
\hline Variable & Coefficient & $\begin{array}{c}\text { Prob. } \\
\text { 1-tailed }\end{array}$ \\
\hline Koefisien & 15,47017 & $0,0000^{* * *}$ \\
\hline DFAM $_{i t}$ & 0,34968 & $0,0000^{* * \times}$ \\
\hline $\mathrm{PBV}_{\mathrm{it}-1}$ & 0,02344 & 0,3373 \\
\hline$A G E_{i t}$ & $-0,00485$ & 0,1740 \\
\hline $\mathrm{EMP}_{\text {it-1 }}$ & 0,00001 & $0,0000^{* *}$ \\
\hline $\mathrm{TA}_{\mathrm{it}}$ & 0,14542 & $0,0001^{* * *}$ \\
\hline $\mathrm{LEV}_{\text {it }}$ & 0,16087 & $0,0001^{* * *}$ \\
\hline $\mathrm{ROA}_{\mathrm{it}-1}$ & $-0,37269$ & $0,0000^{* * *}$ \\
\hline EXESIZE $_{\mathrm{it}}$ & $-0,14389$ & $0,0000^{* k *}$ \\
\hline FIRMAGE $_{i t}$ & 0,09430 & $0,0000^{*+1}$ \\
\hline DFAM $_{\mathrm{it}} * \mathrm{PBV}_{\mathrm{it}-1}$ & 0,01410 & $0,0000^{* * *}$ \\
\hline DCrisis $_{i t}$ & $-0,15064$ & $0,0000^{* * \times}$ \\
\hline$R$-squared & 0,89920 & \\
\hline Adjusted R-squared & 0,87934 & \\
\hline F-statistic & 45,2742 & \\
\hline Prob (F-statistic) & 0,00000 & \\
\hline
\end{tabular}

*** Significant at the 0,01 level; ** Significant at the 0,05 level;

* Significant at the 0,1 level

Variabel dependen dari penelitian adalah logaritma natural total kompensasi yang diterima setiap individu direksi selama 1 tahun (KOM), sedangkan variabel independen penelitian adalah dummy variabel struktur kepemilikan keluarga, apakah perusahaan tersebut termasuk ke dalam perusahaan keluarga atau tidak (DFAM). Dummy variabel PBV di tahun sebelumnya, 1 jika nilai PBV pada tahun sebelumnya bernilai lebih dari satu dan 0 jika di luar kriteria tersebut (DPBV). Interaksi antara dummy variabel struktur kepemilikan keluarga dengan nilai PBV di tahun sebelumnya (DFAM*PBV). AGE adalah usia Direktur Utama. LEV adalah rasio utang perusahaan yang diambil dari utang jangka panjang dibagi nilai total aset. EMP adalah jumlah karyawan perusahaan di tahun sebelumnya. FIRMAGE adalah usia perusahaan sejak tanggal IPO dalam satuan tahun. ROA adalah return on asset di tahun sebelumnya. TA adalah logaritma natural dari total aset dan EXESIZE adalah jumlah Dewan Komisaris.

\section{PEMBAHASAN}

Hubungan positif antara kepemilikan keluarga dan kompensasi eksekutif juga dapat terjadi pada perusahaan-perusahaan dimana anggota keluarga yang lain memegang kontrol lebih, konsisten dengan dugaan bahwa manajer diberikan gaji yang lebih tinggi bukan berdasarkan kinerja sebagai kompensasi namun atas tekanan dari anggota keluarga lain (Cheng et al., 2015). Direktur yang bekerja di perusahaan keluarga menerima premi kompensasi sekitar 30 poin yang tidak dapat dijelaskan oleh karakteristik perusahaan standar atau keterampilan para eksekutif yang dapat diamati (Gallego \& Larrain, 2012). Menurut Gallego \& Larrain (2012), hal ini cenderung terjadi karena perusahaan memiliki fungsi pengawasan kurang baik sehingga biaya keagenan tambahan akan muncul dan direktur dapat meminta premi kompensasi yang tidak terkait dengan standar perusahaan, dengan demikian kompensasi eksekutif pun akan menjadi lebih tinggi sejalan dengan peningkatan kepemilikan oleh sebuah keluarga.

Kompensasi eksekutif di perusahaan keluarga mencerminkan konflik keagenan yang disebabkan oleh keterlibatan anggota keluarga lainnya (Cheng et al., 2015). Pengawasan kompensasi menjadi kurang efektif ketika kepemilikan anggota keluarga tambahan meningkat terutama ketika anggota keluarga memiliki hak pengendalian yang melebihi dari saham yang dimilikinya (AmoakoAdu et al., 2011). Amoako-Adu et al. (2011) dan Masulis et al. (2009) mengemukakan bahwa ketika pemegang saham mayoritas juga menjadi direktur perusahaan dan mengalami pemisahan antara kepemilikan dengan pengendalian, maka jumlah 
kompensasi yang diterimanya akan meningkat. Hal ini dikarenakan pada perusahaan jenis ini, pemegang saham mayoritas akan memiliki insentif untuk melakukan ekspropriasi kekayaan dari pemegang saham minoritas (Morck \& Yeung, 2004). Pemegang saham mayoritas pada perusahaan keluarga memiliki jumlah saham yang besar dan menganggap perusahaan terkait langsung dengan kekayaan keluarga tersebut, hal ini menjadikan mereka memiliki sebuah kepentingan pribadi dalam mengendalikan perusahaan (Shleifer \& Vishny, 1997). Sejalan dengan penelitian La porta et al. (1999) yang mengemukakan bahwa pemegang saham minoritas terpapar ketidakpastian imbal hasil dikarenakan adanya kegiatan ekspropriasi oleh pemegang saham mayoritas dan manajemen, salah satu contoh ekspropriasi ini adalah dengan memberikan kompensasi berlebihan pada manajemen. Berdasarkan hal yang dijelaskan, maka hipotesis $1\left(\mathrm{H}_{1}\right)$ terbukti (diterima) menggunakan hasil estimasi MET.

Variabel dummy PBV pada tahun sebelumnya yang merupakan proksi dari pertumbuhan perusahaan memiliki koefisien positif dengan probabilitas 0,3373 yang berarti variabel ini tidak signifikan dan tidak didukung oleh data dalam menjelaskan jumlah kompensasi yang akan diterima oleh direksi perusahaan. Koefisien di atas sejalan dengan dengan penemuan dari Adhikari et al. (2015) dan Cheng et al. (2015) yang menemukan hubungan positif antara PBV dengan jumlah kompensasi direksi perusahaan. Murphy (1985) dan Core et al. (1999) menemukan bahwa pertumbuhan perusahaan memiliki korelasi positif pada kompensasi direksi perusahaan yang diberikan. Karena semakin tinggi pertumbuhan maka operasional perusahaan semakin kompleks dan membutuhkan manajer yang memiliki kualitas lebih baik, sehingga kompensasi diberikan atas dasar kualitas manajer yang juga lebih tinggi. Namun sayang sekali variabel ini tidak signifikan sehingga hipotesis $2\left(\mathrm{H}_{2}\right)$ tidak terbukti (ditolak).
Hubungan positif menyatakan bahwa perusahaan akan memberikan kompensasi seiring dengan berhasilnya keputusan investasi yang dilakukan oleh direktur, sehingga kompensasi diberikan sebagai sebuah reward atas keberhasilan keputusan investasi yang dibuat oleh direktur, namun hasil yang tidak signifikan menandakan pertumbuhan perusahaan tidak menjadi salah satu faktor penentu bagi perusahaan manufaktur dalam menentuan jumlah kompensasi direksi.

Koefisien variabel interaksi $\mathrm{DFAM}_{\mathrm{it}}{ }^{*} \mathrm{PBV}_{\mathrm{it}-1}$ dapat menangkap perbedaan yang ada terkait sensitivitas jumlah kompensasi direksi terhadap pertumbuhan perusahaan di tahun sebelumnya antara perusahaan keluarga dengan perusahaan non-keluarga. Variabel DFAM ${ }_{\mathrm{it}}{ }^{*} \mathrm{PBV}_{\mathrm{it}-1}$ memiliki koefisien positif dan signifikan pada level 1\%. Koefisien positif menunjukkan bahwa sensitivitas pemberian kompensasi kepada direksi memiliki respon yang lebih kuat terkait pertumbuhan perusahaan pada perusahaan keluarga dibandingkan dengan perusahaan non-keluarga. Perusahaan keluarga yang memiliki pertumbuhan positif dari tahun ke tahun biasanya masih dalam kendali pendirinya sehingga minat investor pada harga saham pun lebih baik, itulah yang membuat investor percaya menaruh dananya pada perusahaan tersebut. PBV yang lebih dari 1 juga menandakan investor menilai saham perusahaan dapat memberikan return yang baik karena adanya peningkatan kualitas dan kinerja serta tata kelola perusahaan yang baik. Perusahaan keluarga biasanya memiliki pertumbuhan yang lebih tinggi dibandingkan dengan perusahaan non-keluarga (Tsao et al., 2015). Perusahaan keluarga yang memiliki pertumbuhan tinggi dan masuk ke dalam Fortune 500 biasanya masih berada dalam manajemen dan dikendalikan oleh pendirinya (Villalonga \& Amit, 2006). Karakteristik ini yang menimbulkan pemikiran bahwa pertumbuhan yang tinggi pada perusahaan keluarga didorong oleh kesadaran dari pemilik perusahaan bahwa pertumbuhan perusaha- 


\section{Jurnal Keuangan dan Perbankan | KEUANGAN}

Vol. 21, No.1, Januari 2017: 14- 24

an adalah hal yang penting bagi perusahaan dan hal ini membuat perusahaan keluarga akan berusaha memberikan kompensasi yang lebih terkait dengan keputusan investasi manajemen.

Sifat risk averse perusahaan keluarga membuat mereka memberikan kompensasi yang lebih tinggi apabila investasi yang dilakukan manajemen menghasilkan keuntungan yang tinggi dengan risiko yang rendah. Hasil penelitian tersebut menunjukkan bahwa hubungan antara keputusan investasi dan kompensasi direksi lebih kuat pada perusahaan keluarga dibandingkan pada perusahaan non-keluarga, hal ini sejalan dengan pendapat Lee \& O'Neill (2003) bahwa perusahaan keluarga memiliki horison jangka panjang yang membuat perusahaan lebih mementingkan keberlangsungan hidupnya dan pertumbuhan perusahaannya melalui investasi. Pandangan perusahaan keluarga terhadap pertumbuhan perusahaan terbukti lebih kuat, hal ini berarti pula bahwa struktur kepemilikan keluarga menjadi moderator dalam hubungan positif antara keputusan investasi perusahaan dengan jumlah kompensasi direksi. Berdasarkan hal yang dijabarkan sebelumnya maka hipotesis $3\left(\mathrm{H}_{3}\right)$ terbukti (diterima).

\section{SIMPULAN DAN SARAN}

\section{Simpulan}

Penelitian ini bertujuan untuk menganalisis pengaruh struktur kepemilikan keluarga dan keputusan investasi terhadap jumlah kompensasi direksi. Penelitian ini juga menguji bagaimana struktur kepemilikan keluarga dan keputusan investasi secara bersama-sama memengaruhi kompensasi direksi perusahaan. Sampel dari penelitian ini adalah perusahaan sektor manufaktur yang terdaftar di BEI pada tahun 2008-2014. Data yang digunakan oleh penulis adalah data sekunder berbentuk panel data yang unbalanced dengan frekuensi data tahunan, sedangkan metode pengolahan data yang digunakan adalah MET. Dari sampel yang digunakan didapatkan bahwa $76 \%$ dari total observasi adalah perusahaan manufaktur yang dimiliki oleh sebuah keluarga. Beberapa kesimpulan yang dapat diambil adalah sebagai berikut: (1) Tipe kepemilikan yang digunakan adalah kepemilikan keluarga dalam bentuk dummy variabel. Perusahaan yang dimiliki oleh sebuah perusahaan keluarga memiliki koefisien positif yang signifikan terhadap kompensasi direksi. Hal ini berarti perusahaan yang dimiliki oleh perusahaan keluarga akan memberikan jumlah kompensasi yang lebih tinggi pada direksinya dibandingkan dengan perusahaan non-keluarga. Hal ini karena perusahaan keluarga di Indonesia menganut sistem struktur piramida, dimana hak voting pemegang saham pengendali melebihi hak cash flow, yang mengakibatkan adanya kegiatan ekstrak manfaat pribadi oleh pemegang saham mayoritas, salah satunya dengan cara memberikan kompensasi berlebih pada eksekutif perusahaan. Hal ini sejalan dengan penelitian Barontini \& Bozzi (2011); (2) Variabel dummy PBV pada tahun sebelumnya merupakan proksi dari pertumbuhan perusahaan. Variabel ini memiliki koefisien positif yang sejalan dengan penemuan Adhikari et al. (2015) dan Cheng et al. (2015) yang menyatakan bahwa pertumbuhan perusahaan akan meningkatkan jumlah kompensasi direksi perusahaan. Namun, variabel ini tidak terbukti secara signifikan akan meningkatkan jumlah kompensasi direksi di tahun berikutnya; dan (3) Variabel interaksi struktur kepemilikan keluarga dengan keputusan investasi memiliki koefisien positif dan signifikan. Koefisien positif menunjukan bahwa sensitivitas pemberian kompensasi kepada direksi memiliki respon yang lebih kuat terkait pertumbuhan perusahaan pada perusahaan keluarga secara signifikan dibandingkan dengan perusahaan non-keluarga. Jenis portofolio yang dimiliki pemegang saham perusahaan keluarga akan membuatnya cenderung menghindari risiko (risk averse) sehingga mereka akan menyukai investasi jangka panjang yang berkelanjutan dengan keuntungan stabil, dibandingkan keuntungan besar jangka pendek yang risikonya besar. 


\section{Dampak Keputusan Investasi dan Struktur Kepemilikan Keluarga...}

Surtihati \& Cynthia Afriani Utama

\section{Saran}

Mengacu pada kesimpulan, maka hasil penelitian ini berimplikasi pada beberapa hal yang dapat disarankan untuk penelitian selanjutnya mengenai kompensasi direksi. Penelitian ini dilakukan hanya pada 1 sektor industri saja (sektor manufaktur) untuk melihat determinan kompensasi direksi secara umum. Bagi akademisi yang tertarik melakukan penelitian mengenai peran atau determinan kompensasi, menambah jumlah sektor yang diteliti dan melakukan wawancara langsung mengenai jumlah kompensasi yang diterima direksi dapat menjadi saran untuk penelitian berikutnya. Penggunaan variabel lain seperti $R \& D$ dapat digunakan sebagai tema penelitian selanjutnya mengingat masih terbatasnya penelitian menggunakan variabel tersebut, bahkan belum ada di Indonesia. R\&D identik dengan inovasi yang dianggap sebagai salah satu strategi bisnis dalam menghadapi kompetisi perusahaan. Penggunaan variabel ini sebagai penentu kompensasi eksekutif perusahaan dan pengaruh struktur kepemilikan keluarga pada inovasi perusahaan di Indonesia sangat menarik untuk diteliti.

Pihak industri juga dapat menjadikan hasil penelitian ini sebagai rujukan dalam menilai peran dan keefektifan kompensasi yang diberikan. Pemberian kompensasi eksekutif yang berlebihan menandakan tata kelola yang kurang baik dan pemberian kompensasi tidak sesuai dengan kontribusi direksi pada perusahaan, sehingga diharapkan perusahaan akan memperbaiki sistem tata kelola perusahaan dan menjalankan pemberian kompensasi sesuai dengan penilaian atas kinerja yang diberikan.

\section{DAFTAR PUSTAKA}

Adhikari, H.P., Bulmash, S.B., Krolikowski, M.W., \& Sah, N.B. 2015. Dynamics of CEO Compensation: Old is Gold. The Quarterly Review of Economics and Finance, 57(C): 191-206.
Amoako-Adu, B., Baulkaran, V., \& Smith, B.F. 2011. Executive Compensation in Firms with Concentrated Control: The Impact of Dual Class Structure and Family Management. Journal of Corporate Finance, 17(5): 1580-1594.

Anderson, R.C. \& Reeb, D.M. 2003. Founding-Family Ownership and Firm Performance: Evidence from the S\&P 500. The Journal of Finance, 58(3): 13011328.

Barontini, R. \& Bozzi, S. 2011. Board Compensation and Ownership Structure: Empirical Evidence for Italian Listed Companies. The Journal of Management and Governance, 15(1): 59-89.

Barontini, R. \& Caprio, L. 2006. The Effect of Family Control on Firm Value and Performance: Evidence from Continental Europe. European Financial Management, 12(5): 689-723.

Benos, E. \& Weisbach, M. 2004. Private Benefits and CrossListings in the United States. Emerging Markets Review, 5(2): 217-240.

Brick, I.E., Palmon, O., \& Wald, J.K. 2006. CEO Compensation, Director Compensation, and Firm Performance: Evidence of Cronyism? Journal of Corporate Finance, 12(3): 403-423.

Brenes, E.R., Madrigal, K., \& Requena, B. 2011. Corporate Governance and Family Business Performance. Journal of Business Research, 64(3): 280-285.

Cheng, M., Lin, B., \& Wei, M. 2015. Executive Compensation in Family Firms: The Effect of Multiple Family Members. Journal of Corporate Finance, 32: 238-257.

Claessens, S. \& Fan, J.P.H. 2002. Corporate Governance in Asia: A Survey. International Review of Finance, 3(2): 71-103.

Claessens, S., Djankov, S., \& Lang, L.H.P. 2000. The Separation of Ownership and Control in East Asian Corporations. Journal of Financial Economics, 58(12): 81-112.

Cohen, S. \& Lauterbach, B. 2008. Differences in Pay between Owner and Non-Owner CEOs: Evidence from Israel. Journal of Multinational Financial Management, 18(1): 4-15.

Coles, J.W., McWilliams, V.B., \& Sen, N. 2001. An Examination of the Relationship of Governance Mecha- 


\section{Jurnal Keuangan dan Perbankan | KEUANGAN}

Vol. 21, No.1, Januari 2017: 14- 24

nisms to Performance. Journal of Management, 27(1): 23-50.

Core, J.E., Holthausen, R.W., \& Larcker, D.F. 1999. Corporate Governance, Chief Executive Officer Compensation, and Firm Performance. Journal of Financial Economics, 51(3): 371-406.

Croci, E., Gonenc, H., \& Ozkan, N. 2012. CEO Compensation, Family Control, and Institutional Investors in Continental Europe. Journal of Banking and Finance, 36(12): 3318-3335.

Gallego, F. \& Larrain, B. 2012. CEO Compensation and Large Shareholders: Evidence from Emerging Markets. Journal of Comparative Economics, 40(4): 621-642.

Jensen, M.C. \& Meckling, W.H. 1976. Theory of the Firm: Managerial Behavior, Agency Costs, and Ownership Structure. Journal of Financial Economics, 3(4): 305-360.

La Porta, R., Lopez-de-Silanes, F., \& Shleifer, A. 1999. Corporate Ownership Around the World. Journal of Finance, 54(2): 471-517.

Lee, P.M., \& O'Neill, H.M. 2003. Ownership Structures and R\&D Investments of US and Japanese Firms: Agency and Stewardship Perspectives. Academy of Management Journal, 46(2): 212-225.

Masulis, R.W., Wang, C., \& Xie, F. 2009. Agency Problems at Dual-Class Companies. The Journal of Finance, 64(4): 1697-1727.
Morck, R. \& Yeung, B. 2003. Agency Problems in Large Family Business Groups. Entrepreneurship Theory and Practice, 27(4); 367-382.

Morck, R., \& Yeung, B. 2004. Family Control and the RentSeeking Society. Entrepreneurship Theory and Practice, 28(4): 391-409.

Murphy, K.J. 1985. Corporate Performance and Managerial Remuneration: An Empirical Analysis. Journal of Accounting and Economics, 7(1-3): 11-42.

Shleifer, A. \& Vishny, R.W. 1997. A Survey of Corporate Governance. The Journal of Finance, 52: 737-783.

Tsao, S., Lin, C., \& Chen, V.Y.S. 2015. Family Ownership as A Moderator between R\&D investments and CEO compensation. Journal of Business Research, 68(3): 599-606.

Utama, C.A. 2003. Tiga Bentuk Masalah Keagenan (Agency Problem) dan Alternatif Pemecahannya. Usahawan, 1(32).

Villalonga, B. \& Amit, R. 2006. How do Family Ownership, Control, and Management Affect Firm Value? Journal of Financial Economics, 80(2): 385-417.

Wu, C. 2013. Family Ties, Board Compensation, and Firm Performance. Journal of Multinational Financial Management, 23(4): 255-271. 